\title{
Awareness of the Faculty Members at Al-Balqa` Applied University to the Concept of Time Management and Its Relation to Some Variables
}

\author{
Raed Adel Sabha ${ }^{1} \&$ Jamal Abdel-Fattah Al-Assaf ${ }^{2}$ \\ ${ }^{1}$ Social and Applied Sciences Department, Faculty of Princess Alia University College, Amman, Jordan \\ ${ }^{2}$ Educational Department, Faculty of Princess Alia University College, Amman, Jordan \\ Correspondence: Raed Adel Sabha, Social and Applied Sciences Department, Faculty of Princess Alia \\ University College, Amman, Jordan. Tel: 962-6568-1567. Fax: 962-6568-6741. E-mail: gami3at@yahoo.com
}

\author{
Received: May 25, 2012 Accepted: June 5, 2012 Online Published: August 8, 2012 \\ doi:10.5539/ies.v5n5p116 URL: http://dx.doi.org/10.5539/ies.v5n5p116
}

\begin{abstract}
The study aims to investigate how extent is the time management awareness of the faculty members of the Al-Balqa' Applied university, and its relation to some variables. The study conducted on (150) teachers were selected randomly. For achieving the study goals an appropriate instrument has been built up based on the educational literature and former studies.

The study has found out that the teachers' awareness were "good", where the planning awareness was the highest, and the execution one was the lowest, also the role of the time management in career life was more visible than the personal life.

The study also found out that the variables of the study have a weak impact on the teachers' time management awareness.
\end{abstract}

Keywords: faculty members`awareness, time management

\section{Introduction}

Time is considered as one of the most important resources as all other resources related to it within its availability or shortage. Moreover, all tasks wither it was simple or small need time. Time has its own characteristics since it's in continuous motion that can't be stopped and it can't be saved. It is a fixed quantity resource within 24 hours a day for all individuals and it can't be retrieved too (Haynez, 2006).

Those characteristics make it necessary to deal with time through wisdom and careful usage that must be dealt with in a certain way as people differ in their usage of time according to their type of work. However, must people describe time differently according to their perceptions, some says: it passes quickly, or it is a short time. Others may say there is no enough time. All those expression depend on the availability of a given time and the ability to carry out a series of tasks. This means, individuals are compared by the time available to them and the load of work and its compared through the ability to carry out work versus the available time, those comparisons generate those expressions

Time management is the process of using time thoroughly by doing all jobs in the available time; this needs the good knowledge and practice of time for each job then distributing time on a timetable to be able to do all need work successfully. However, all this doesn't ensure the absence of problems and difficulties that are not under the individual's control. Though, the repeated practice of time management can train the individual to overcome those difficulties and learn how to put the needed solutions in order to acquire a storage of different solutions and ready alternatives to be used when needed.

The investment of time and managing it in the first place means building an essential pillar in re-arranging priorities and work habits in away maximizing the benefits from the available time and reducing wasted time (Marsh, 1991).

Mackenze (2000: 5) defined time management as a comprehensive concept for every place and time or for every person or community or even an environment. When we think of time management, however, we tend to think of 
personal time management, loosely defined as managing our time to waste less time on doing the things we have to do so we have more time to do the things we want to do.

Plater (1995) stated in an article published in human resources journal ( time type in the $21^{\text {st }}$ century) that time is the most important advantage for administrators and time management makes their work important and productive more than anything else (P4).

Chaplin Taylor, argued that time is the most rigid and flexible thing in this universe. However, we can say that it can be managed effectively, and if not, we will not be able to manage anything else (Machenzie, 1990:4).

Birth (1993: 352) stated that time management is one of the most important processes in any organization as it reflects the civilized concepts in using time and the nature of social interactions; this requires designing models that focus on managing time to serve the organization's objectives. Dealing with time becomes increasingly as the accurate lens for that day and its accomplishments as well as the nature of interaction between individuals and organizations and enhances its importance in representing the civilized aspect for the its interaction to serve the community.

In their study Trueman and Hartley (1999) concluded that differences in time management among university students according to age and gender were in the favor of females. Moreover, they concluded that there were differences in time management according to age variable in the favor of males for the age category (more than $25 \mathrm{yrs})$, and those variable can predict the academic performance of the students weakly.

On the other hand, Macan et al (1990) conducted a study to explore the relation between time management, academic performance and tension among English students in colleges. The (123) students sample showed that there is a positive relation between time management, academic performance and tension

\section{Statement of Purpose}

The problem of this study occurred for the researchers during their administrative work in the university and their discussions with faculty members. It was evident that mentors don't appreciate the value of time whether in their teaching tasks nor in their attendance of meetings in sections. This encouraged the researchers to conduct a study to explore this issue in relation to answering the following questions:

- What is the extent of awareness among Faculty members in Al-balqa University of time management concept?

- What are the effects of scientific qualification, academic experience, gender, major and academic rank on the awareness of time management among Faculty members in Al-balqa University?

\section{Significance of the Study}

The current study importance emerges from the importance of time element as it is a main element in the production process and a major resource of any organization, and the role of the university teaches in final stages of the teaching process before the students being apart of the working power in the society. The importance of this study can be summarized as follows:

- The study may benefit faculty members in promoting their administrative performance by exploring their level of time management.

- Universities may benefit from the findings of this study through exploring the strength and weakness aspects in time management among faculty members study.

- The ministry of Higher Education may benefit from the recommendations of this study in conducting training courses for faculty members.

\section{Operational Definitions}

- Time Management: Using time thoroughly by applying the management phases: planning, organization, execution, evaluation. It is measured in this study according to the answers of the sample on the study instrument.

- Faculty members: Academic persons working in Al-balqa applied university in the academic year 2011/2012.

\section{Methodology}

The researchers adopted the survey descriptive approach to investigate the awareness of the faculty members at Al-Balqa`Applied University to the concept of time management and its relation to some variables. 


\subsection{Study Population}

The population of this study consisted of all faculty members in Al-balqa applied university totaling (1100 members).

\subsection{Study Sample}

The sample of this study was chosen randomly totaling (150) faculty members, and it representing (13\%) of the population. Table (1) presents the characteristics of the sample

Table 1. Characteristics of the sample

\begin{tabular}{|c|c|c|}
\hline \multicolumn{3}{|l|}{ Scientific Qualification } \\
\hline Bachelor & 7 & 4.7 \\
\hline Master & 47 & 31.3 \\
\hline PhD & 96 & 64.0 \\
\hline Total & 150 & 100.0 \\
\hline \multicolumn{3}{|l|}{ Academic Rank } \\
\hline Assistant Teacher & 7 & 4.7 \\
\hline Teacher & 47 & 31.3 \\
\hline Assistant Professor & 76 & 50.7 \\
\hline Associate Professor & 16 & 10.7 \\
\hline Professor & 4 & 2.7 \\
\hline Total & 150 & 100.0 \\
\hline \multicolumn{3}{|l|}{ Gender } \\
\hline Male & 87 & 58.0 \\
\hline Female & 63 & 42.0 \\
\hline Total & 100 & 100.0 \\
\hline \multicolumn{3}{|l|}{ Major } \\
\hline Educational sciences & 73 & 48.7 \\
\hline Social sciences & 18 & 12.0 \\
\hline Legitimacy sciences & 4 & 2.7 \\
\hline Linguistic sciences & 25 & 16.7 \\
\hline Management sciences & 12 & 8.0 \\
\hline Agriculture sciences & 4 & 2.7 \\
\hline Applied sciences & 14 & 9.3 \\
\hline Total & 150 & 100.0 \\
\hline \multicolumn{3}{|l|}{ Academic Experience } \\
\hline Less than $2 y r s$ & 12 & 8.0 \\
\hline $2-5 y r s$ & 58 & 38.7 \\
\hline 6-10yrs & 44 & 29.3 \\
\hline More than 10yrs & 36 & 24.0 \\
\hline Total & 100 & 100.0 \\
\hline
\end{tabular}

\subsection{Instrumentation}

The study instrument is a questionnaire directed to the faculty members in Al-balqa applied university. The questionnaire is aiming to investigate the awareness of the faculty members at Al-Balqa'Applied University to 
the concept of time management. The questionnaire consisted of six domains: planning, organization, execution, evaluation, role of time management in personal life, role of time management in Job. Each domain contained of 10 items to measure the awareness of the sample according to 5- likert scale (extremely agree, agree, none, disagree, extremely disagree).

The questionnaire was delivered to respondents then analyzed using (SPSS) package. Each item was given the following scores: (extremely agree: 5 , agree: 4 , none: 3 , disagree: 2 , extremely disagree: 1 . The total number of items on each domain are 50 and the best answer is "extremely agree" for all. The total of items scores expresses the awareness degree of the faculty member, and (300) representing the best total.

Answers in each domain were organized according to the following table.

\begin{tabular}{ll}
\hline Total scores of each domain & The meaning in relation to awareness \\
\hline 50 & Excellent awareness \\
$40-49$ & Very good awareness \\
$30-39$ & Good awareness \\
Less than or equal 29 & Weak awareness \\
\hline
\end{tabular}

The answers of each respondent were expressed according to the following table:

\begin{tabular}{ll}
\hline Total scores of the questionnaire & The meaning in relation to awareness \\
\hline 300 & Excellent awareness \\
$240-299$ & Very good awareness \\
$180-239$ & Good awareness \\
Less than or equal 179 & Weak awareness \\
\hline
\end{tabular}

The means of faculty members' awareness can be expressed as in the following table:

\begin{tabular}{ll}
\hline Mean value & The meaning in relation to awareness \\
\hline $4.5-5$ & Excellent awareness \\
$4-4.5$ & Very good awareness \\
$3.5-4$ & Good awareness \\
3- less than 3.5 & Accepted awareness \\
Less than 3 & Weak awareness \\
\hline
\end{tabular}

\subsubsection{Instrument Validity}

Validity was established through content and face validity, and the instrument was standardized on the response of (20) experts of psychology, curriculum, teaching methods, and measurement and evaluation at Jordanian universities. Those experts were asked to comment on and discuss any part of the instrument they might consider to be ambiguous.

\subsubsection{Instrument Reliability}

Reliability of the instrument was determined through internal constancy coefficient using Alpha Coefficient. Table (2) presents the alpha coefficients

Table 2. Reliability alpha coefficients

\begin{tabular}{ll}
\hline Domain & Alpha coefficients \\
\hline Planning & 0.68 \\
organization & 0.69 \\
Evaluation & 0.74 \\
Personal life & 0.80 \\
Job life & 0.66 \\
Total & 0.81 \\
\hline
\end{tabular}




\subsection{Study Variables}

\subsubsection{Independent Variables}

1) Scientific Qualification: Batchelor, Master, $\mathrm{PhD}$.

2) Gender: Male. Female.

3) Major: Educational sciences, Social sciences, Legitimacy sciences, Linguistic sciences, Management sciences, Agriculture sciences and applied sciences.

4) Academic Rank: Assistant Teacher, Teacher, Assistant Professor, Associate Professor and Professor.

5) Experience: Less than 2yrs, 2-5yrs, 6-10yrs, More than 10yrs.

\subsubsection{Dependent Variables}

Represented in the extent of awareness of time management concept .among faculty members at Al- Balqa applied university

\section{Results \& Discussion}

6.1 What is the Extent of Awareness of Time Management Concept among Faculty Members in Al-balqa University?

Table (3) presents a summary of faculty members' awareness of planning, organization, execution, evaluation, and role of time management in personal life and job life in general, through means and maximum as well as minimum values in addition to Standard deviations.

Table 3. Faculty members' awareness summarization

\begin{tabular}{|c|c|c|c|c|c|}
\hline & $\begin{array}{l}\text { Mean } \\
\text { (awareness) }\end{array}$ & $\begin{array}{l}\text { Maximum } \\
\text { mean }\end{array}$ & $\begin{array}{l}\text { Minimum } \\
\text { mean }\end{array}$ & $\begin{array}{l}\text { Standard } \\
\text { deviation }\end{array}$ & $\begin{array}{l}\text { Rank of the } \\
\text { awareness }\end{array}$ \\
\hline Awareness of Planning & 4.032 & 4.6 & 3.4 & 0.3530 & 1 (v. good) \\
\hline Awareness of organizatic & 3.675 & 4.3 & 2.8 & 0.3358 & $3($ good $)$ \\
\hline Awareness of execution & 3.210 & 3.9 & 2.6 & 0.252 & $6($ accepted $)$ \\
\hline Awareness of evaluation & 3.485 & 4.7 & 2.4 & 0.599 & $4($ accepted ++$)$ \\
\hline $\begin{array}{l}\text { Role of time } \\
\text { management in } \\
\text { Personal life }\end{array}$ & 3.463 & 4.5 & 2.5 & 0.589 & $5($ accepted +$)$ \\
\hline $\begin{array}{l}\text { Role of time } \\
\text { management in Job life }\end{array}$ & 4.024 & 5.0 & 3.0 & 0.410 & 2 (v. good) \\
\hline $\begin{array}{l}\text { General time } \\
\text { management } \\
\text { awareness }\end{array}$ & 3.648 & 4.2 & 3.1 & 0.255 & good \\
\hline
\end{tabular}

$(+)$ represents the level in the same range of the mean. as $(+)$ increases the awareness increases in the same range of mean.

Appears from the table (3) that the awareness of faculty members to the concept of planning was the highest, and awareness of the concept of execution was the lowest, and the role of time management in the job was more visible than its role in personal life, and this could indicate the adoption of the teachers on the dates specified in advance calendars university, as well as courses ' plans in the planning of their performance, but when it comes to their ability of self-organization, or execution, or evaluation, or the application of time management in their personal lives; they show a weakness in their understanding or application of the concepts of time management, while showing that the average general awareness of the concept of time management was "good" as well. Appendix (1) presents all the aspects of awareness regarding time management concept. 
6.2 What Are the Effects of Scientific Qualification, Academic Experience, Gender, Major and Academic Rank on the Awareness of Time Management among Faculty Members in Al-balqa University?

6.2.1 Effects of Scientific Qualification, Academic Experience, Gender, Major and Academic Rank on Planning Concept Awareness

Using Spearman test for correlation to explore the nature relationship between the five independent variables and the dependent variable (planning awareness), it was found that there is no relation as presented in Table (4).

Table 4. Correlations

\begin{tabular}{llllllll}
\hline & & $\begin{array}{l}\text { scientific } \\
\text { qualification }\end{array}$ & $\begin{array}{l}\text { academic } \\
\text { rank }\end{array}$ & sex & major & $\begin{array}{l}\text { academic } \\
\text { experience }\end{array}$ & $\begin{array}{l}\text { plan } \\
\text { awareness }\end{array}$ \\
\hline $\begin{array}{l}\text { Spearman`s plan awareness Correlation } \\
\text { rho }\end{array}$ & .116 & .067 & .016 & .054 & -.135 & 1.000 \\
& $\begin{array}{l}\text { Coefficient } \\
\text { Sig. }\end{array}$ & .156 & .415 & .844 & .513 & .099 &. \\
& $\begin{array}{l}(2 \text {-tailed) } \\
\mathrm{N}\end{array}$ & 150 & 150 & 150 & 150 & 150 & 150 \\
\hline
\end{tabular}

** Correlation is significant at the .01 level (2-tailed).

* Correlation is significant at the .05 level (2-tailed).

This could be attributed to teachers work within the university system regulation regarding the dates and specific dates in advance, both in terms of dates of lectures, or dates of other academic procedures such as tests, holidays, start and end of the academic year, meaning that there are other variables affecting the awareness of teachers to the concept of planning not including what is mentioned in the study.

6.2.2 Effects of Scientific Qualification, Academic Experience, Gender, Major and Academic Rank on Organization Concept Awareness

Using Spearman test for correlation to explore the nature relationship between the five independent variables and the dependent variable (organization awareness) it was found that there is a weak reversal relation according to scientific qualification and gender. Meanwhile, a weak positive relationship according to major, data are shown on Table (5-1).

Table (5-1). Correlations

\begin{tabular}{|c|c|c|c|c|c|c|c|}
\hline & & $\begin{array}{l}\text { scientific } \\
\text { qualification }\end{array}$ & $\begin{array}{l}\text { academic } \\
\text { rank }\end{array}$ & sex & major & $\begin{array}{l}\mathrm{r} \text { academic } \\
\text { experience }\end{array}$ & $\begin{array}{l}\text { organization } \\
\text { awareness }\end{array}$ \\
\hline \multirow[t]{3}{*}{$\begin{array}{ll}\text { Spearman's } & \text { organization } \\
\text { rho } & \text { awareness }\end{array}$} & $\begin{array}{l}\text { Correlation } \\
\text { Coefficient }\end{array}$ & -.218 & -.137 & -.216 & .189 & .082 & 1.000 \\
\hline & Sig. (2-tailed) & $.007 * *$ & .094 & $.008^{* *}$ & $.021 *$ & .320 & . \\
\hline & $\mathrm{N}$ & 150 & 150 & 150 & 150 & 150 & 150 \\
\hline
\end{tabular}

** Correlation is significant at the .01 level (2-tailed).

* Correlation is significant at the .05 level (2-tailed).

The findings of the correlation test showed that the high scientific qualification of the teacher the least awareness of the concept of organization, this means that his practice doesn't reflect awareness of organization. This could be attributed to the professor thoughts that his high qualification makes his practices correct without any need for evaluation. It also indicated that female teachers were less awareness in organizing concept, this may be attributed to the nature of the roles overlapping of women in Jordanian society; of Mother, and follow-up family, and social relations, in addition to their academic roles which makes it difficult doing the exercise organization well .

The relationship of major and awareness of teachers to the concept of organization was the direct correlation, and this means that the disciplines of applied, agricultural, and administrative best aware of the concept of 
organization of multidisciplinary educational and social legitimacy, it may be due to the nature of specialization, which formulates the mind of the individual, scientific tougher on the issue of the use of time, most applications linked in time, any time that the determinants of success and failure, so they are more aware of the concept of time organization of other disciplines.

To investigate the effects of independent variables on the dependent variable multiple regression analysis was carried out to explore the weakness of independent variables ability on explaining the variance or predicting the awareness of organization concept among faculty members. It was noted that $\mathrm{R}^{2}$ value is $(0.099)$ and $F$ value is (3.161) at the level of significance (0.01), indicating an effect for all variables on the awareness of organization concept as shown in table (5-2).

Table (5-2). Multi-regression results

Model Summary

\begin{tabular}{llllll}
\hline Model & R & R Square & $\begin{array}{l}\text { Adjusted } \\
\text { Square }\end{array}$ & $\begin{array}{c}\text { RStd. Estimate } \\
\text { Estim of the }\end{array}$ \\
\hline 1 & .315 & .099 & .068 & .43 & \\
\hline
\end{tabular}

a. Predictors: (Constant), academic experience, education level, sex, major, academic rank ANOVA

\begin{tabular}{lllllll}
\hline Model & & $\begin{array}{l}\text { Sum } \\
\text { Squares }\end{array}$ & ofdf & Mean SquareF & Sig. \\
\hline 1 & Regression & 2.904 & 5 & .581 & 3.161 & .010 \\
& Residual & 26.456 & 144 & .184 & & \\
& Total & 29.360 & 149 & & & \\
&
\end{tabular}

a. Predictors: (Constant), academic experience, education level, sex, major, academic rank

b. Dependent Variable: organization awareness

6.2.3 Effects of Scientific Qualification, Academic Experience, Gender, Major and Academic Rank on the Awareness of Execution Concept

Using Spearman test for correlation to explore the nature relationship between the five independent variables and the dependent variable (execution awareness) it was found that there is a weak reversal relation according to major and academic experience. Table (6-1)

Table (6-1). Correlations

\begin{tabular}{|c|c|c|c|c|c|c|}
\hline & & & $\begin{array}{l}\text { scientific } \\
\text { qualification }\end{array}$ & $\begin{array}{l}\text { academic } \\
\text { rank }\end{array}$ & $\begin{array}{l}\text { sex major academic } \\
\text { experience }\end{array}$ & $\begin{array}{l}\text { execution } \\
\text { awareness }\end{array}$ \\
\hline \multirow[t]{3}{*}{$\begin{array}{l}\text { Spearman's } \\
\text { rho }\end{array}$} & \multirow[t]{3}{*}{$\begin{array}{l}\text { execution } \\
\text { awareness }\end{array}$} & $\begin{array}{l}\text { Correlation } \\
\text { Coefficient }\end{array}$ & .086 & -.002 & $\begin{array}{ll}127-.259 & -.199\end{array}$ & 1.000 \\
\hline & & Sig. (2-tailed) & .297 & .976 & $.122 .001 * * .015 *$ & . \\
\hline & & $\mathrm{N}$ & 150 & 150 & 150150 & 150 \\
\hline
\end{tabular}

** Correlation is significant at the .01 level (2-tailed)

* Correlation is significant at the .05 level (2-tailed).

The findings showed that teachers of applied and agricultural majors are the lowest category in the awareness of execution concept compared by educational and social majors; this can be attributed to the close relation of last majors with the social life more than applied and agricultural majors that are related to vocational life of any person. As well as the teachers with years of experience the largest less aware of the concept of execution of the less experienced, may be due to accustomed to a specific consistent pattern acquired during the years of their 
academic work, and thus not their awareness of errors repeated that might fall in, those with considerable experience often think they know everything for their job, they are less accepting of change.

To investigate the effects of independent variables on the dependent variable multiple regression analysis was carried out to explore the weakness of independent variables ability on explaining the variance or predicting the awareness of execution concept among faculty members. It was noted that $R^{2}$ value is $(0.081)$ and $F$ value is (2.554) at the significance level (0.03) indicating an effect for all variables on the awareness of execution concept as shown in table (6-2).

Table (6-2). Multi-regression results

Model Summary

\begin{tabular}{llllll}
\hline Model & $\mathrm{R}$ & R Square & $\begin{array}{l}\text { Adjusted } \\
\text { Square }\end{array}$ & $\begin{array}{l}\text { RStd. Error } \\
\text { Estimate }\end{array}$ & of the \\
\hline 1 & .285 & .081 & .050 & .36
\end{tabular}

a. Predictors: (Constant), academic experience, education level, sex, major, academic rank

ANOVA

\begin{tabular}{lllllll}
\hline Model & & \multicolumn{2}{l}{$\begin{array}{l}\text { Sum ofdf } \\
\text { Squares }\end{array}$} & & Mean SquareF & Sig. \\
\hline 1 & Regression & 1.697 & 5 & .339 & 2.554 & .030 \\
& Residual & 19.136 & 144 & .133 & & \\
& Total & 20.833 & 149 & & & \\
\hline
\end{tabular}

a. Predictors: (Constant), academic experience, education level, sex, major, academic rank

b. Dependent Variable: execution awareness

6.2.4 Effects of Scientific Qualification, Academic Experience, Gender, Major and Academic Rank on the Level of Evaluation Concept Awareness

Using Spearman test for correlation to explore the nature relationship between the five independent variables and the dependent variable (evaluation awareness) it was found that there is a medium reversal relation according to major and academic experience, and a positive medium relationship according to gender. Table (7-1)

Table (7-1). Correlations

\begin{tabular}{|c|c|c|c|c|c|c|}
\hline & & & $\begin{array}{l}\text { scientific } \\
\text { qualification }\end{array}$ & $\begin{array}{l}\text { academic } \\
\text { rank }\end{array}$ & $\begin{array}{l}\text { sex majoracademic } \\
\text { experience }\end{array}$ & $\begin{array}{l}\text { evaluation } \\
\text { awareness }\end{array}$ \\
\hline \multirow[t]{3}{*}{$\begin{array}{l}\text { Spearman's } \\
\text { rho }\end{array}$} & $\begin{array}{l}\text { evaluation } \\
\text { awareness }\end{array}$ & $\begin{array}{l}\text { Correlation } \\
\text { Coefficient }\end{array}$ & .045 & -.113 & $.309-.450-.371$ & 1.000 \\
\hline & & Sig. (2-tailed) & .587 & .170 & $\begin{array}{ll}.000 .000 & .000\end{array}$ & . \\
\hline & & $\mathrm{N}$ & 150 & 150 & 150150 & 150 \\
\hline
\end{tabular}

** Correlation is significant at the .01 level (2-tailed).

* Correlation is significant at the .05 level (2-tailed).

The findings showed that teachers of applied and agricultural majors are the lowest category in the awareness of evaluation concept compared by Educational and social majors. This can be attributed to the link between educational and social majors with social life more than Applied and agricultural-related careers and business. As well as the teachers with more years of experience are less awareness of the concept of evaluation than the less experienced, may be due to their belief that they know everything about their job, it is impossible to fall into the errors. 
With regard to gender relation there is a positive medium relation, this means that female teachers are better than males; this may be due to the community's role in loading multiple responsibilities of women, asking them to good performance in all things, which made them used to assess things.

To investigate the effects of independent variables on the dependent variable multiple regression analysis was carried out to explore the weakness of independent variables ability on explaining the variance or predicting the awareness of evaluation concept among faculty members. It was noted that $R^{2}$ value is $(0.239)$ and $F$ value is (9.058) at the level of (0.00) indicating an effect for all variables on the awareness of evaluation concept as shown in table (7-2).

Table (7-2). Multi-regression results

Model Summary

\begin{tabular}{lllllll}
\hline Model & R & R Square & $\begin{array}{l}\text { Adjusted } \\
\text { Square }\end{array}$ & $\begin{array}{l}\text { RStd. Error } \\
\text { Estimate }\end{array}$ & of the \\
\hline 1 & .489 & .239 & .213 & .61 & \\
\hline
\end{tabular}

a. Predictors: (Constant), academic experience, education level, sex, major, academic ran

ANOVA

\begin{tabular}{lllllll}
\hline Model & & $\begin{array}{l}\text { Sum } \\
\text { Squares }\end{array}$ & ofdf & $\begin{array}{l}\text { Mean } \\
\text { Square }\end{array}$ & F & Sig. \\
\hline 1 & Regression & 17.107 & 5 & 3.421 & 9.058 & .000 \\
& Residual & 54.393 & 144 & .378 & & \\
& Total & 71.500 & 149 & & & \\
\end{tabular}

a. Predictors: (Constant), academic experience, education level, sex, major, academic rank

b. Dependent Variable: evaluation awareness

6.2.5 Effects of Scientific Qualification, Academic Experience, Gender, Major and Academic Rank on the Role of Time Management in Personal Life of the Faculty Members

Using Spearman test for correlation to explore the relationship nature between the five independent variables and the dependent variable (time management role in personal life) it was found that there is a medium reversal relation according to scientific qualification (major), and academic experience, and a positive relationship according to gender as seen in Table (8-1).

Table (8-1). Correlations

\begin{tabular}{|c|c|c|c|c|c|c|}
\hline & & & $\begin{array}{l}\text { scientific } \\
\text { qualification }\end{array}$ & $\begin{array}{l}\text { academic } \\
\text { rank }\end{array}$ & $\begin{array}{l}\text { sex majoracademic } \\
\text { experience }\end{array}$ & $\begin{array}{l}\text { personal } \\
\text { performance }\end{array}$ \\
\hline \multirow[t]{3}{*}{$\begin{array}{l}\text { Spearman's } \\
\text { rho }\end{array}$} & $\begin{array}{l}\text { personal } \\
\text { performance }\end{array}$ & $\begin{array}{l}\text { Correlation } \\
\text { Coefficient }\end{array}$ & .107 & -.061 & $.284-.394-.422$ & 1.000 \\
\hline & & Sig. (2-tailed) & .193 & .457 & .000.000. & . \\
\hline & & $\mathrm{N}$ & 150 & 150 & 150150 & 150 \\
\hline
\end{tabular}

** Correlation is significant at the .01 level (2-tailed).

*Correlation is significant at the .05 level (2-tailed).

The findings showed that teachers of applied and agricultural majors are applying time management in their life less than teachers of educational and social majors' teachers; this can be attributed to the link between educational and social majors with social life more than Applied and agricultural-related careers and business. Thus teachers with more experience are less application of time management in their personal life, this may be due to their assumption that they know everything about time management. With regard to gender relation there 
is a positive relation, this means that female teachers are better than males; this may be due to the community's role in loading multiple responsibilities of women, asking them to good performance in all things.

To investigate the effects of independent variables on the dependent variable multiple regression analysis was carried out to explore the weakness of independent variables ability on explaining the variance or predicting the awareness of applying time management in personal life among faculty members. It was noted that $\mathrm{R}^{2}$ value is $(0.274)$ and $F$ value is $(10.868)$ at significance level of $(0.00)$ indicating an effect for all variables on the awareness of applying time management in personal life as shown in table (8-2).

Table (8-2). Multi-regression results

Model Summary

\begin{tabular}{lllll}
\hline Model & $\mathrm{R}$ & $\mathrm{R}$ Square & $\begin{array}{l}\text { Adjusted } \\
\text { Square }\end{array}$ & RStd. Error of the Estimate \\
\hline 1 & .523 & .274 & .249 & .59
\end{tabular}

a. Predictors: (Constant), academic experience, education level, sex, major, academic rank

ANOVA

\begin{tabular}{lllllll}
\hline Model & & $\begin{array}{l}\text { Sum } \\
\text { Squares }\end{array}$ & ofdf & $\begin{array}{l}\text { Mean } \\
\text { Square }\end{array}$ & F & Sig. \\
\hline 1 & Regression & 18.756 & 5 & 3.751 & 10.868 & .000 \\
& Residual & 49.704 & 144 & .345 & & \\
& Total & 68.460 & 149 & & & \\
\hline
\end{tabular}

a. Predictors: (Constant), academic experience, education level, sex, major, academic rank

b. Dependent Variable: personal performance

6.2.6 Effects of Scientific Qualification, Academic Experience, Gender, Major and Academic Rank on the Role of Time Management in Job Life

Using Spearman test for correlation to explore the nature between the five independent variables and the dependent variable (role of time management in Job life) it was found that there is a weak reversal relation according to scientific qualification (major) and academic experience, as seen in Table (9-1).

Table (9-1). Correlations

\begin{tabular}{|c|c|c|c|c|c|c|}
\hline & & & $\begin{array}{l}\text { scientific } \\
\text { qualification }\end{array}$ & $\begin{array}{l}\text { academic } \\
\text { rank }\end{array}$ & $\begin{array}{l}\text { sex majoracademic } \\
\text { experience }\end{array}$ & $\begin{array}{l}\text { work life } \\
\text { performance }\end{array}$ \\
\hline \multirow[t]{3}{*}{$\begin{array}{l}\text { Spearman's } \\
\text { rho }\end{array}$} & \multirow[t]{3}{*}{$\begin{array}{l}\text { work } \\
\text { performance }\end{array}$} & $\begin{array}{r}\text { lifeCorrelation } \\
\text { Coefficient }\end{array}$ & .025 & .043 & $.106-.231-.239$ & 1.000 \\
\hline & & Sig. (2-tailed) & .761 & .602 & . $196.004 \quad .003$ & . \\
\hline & & $\mathrm{N}$ & 150 & 150 & 150150 & 150 \\
\hline
\end{tabular}

** Correlation is significant at the .01 level (2-tailed).

* Correlation is significant at the .05 level (2-tailed).

The findings showed that teachers with specialties of applied and agricultural are less application of time management in their careers than teachers with interdisciplinary educational, and social, and may be the significance of this return to the link-disciplinary educational and social with individuals behaviors. As well as the teachers with less years of experience are less in application of time management in their career of less experienced, may be due to their conviction that they know everything about their job, and the level of their management aspects of their job is the best, so they are less accepting of change 
To investigate the effects of independent variables on the dependent variable multiple regression analysis was carried out to explore the weakness of independent variables ability on explaining the variance or predicting the awareness of applying time management in job life among faculty members. It was noted that $\mathrm{R}^{2}$ value is $(0.12)$ and $F$ value is (3.931) at the level of (0.02) indicating and effect foe all variables on the awareness of applying time management in job life concept as shown in table (9-2).

Table (9-2). Multi-regression results

Model Summary

\begin{tabular}{lllll}
\hline Model & R & R Square & $\begin{array}{l}\text { Adjusted } \\
\text { Square }\end{array}$ & RStd. Error of the Estimate \\
\hline 1 & .347 & .120 & .090 & .52 \\
\hline
\end{tabular}

a. Predictors: (Constant), academic experience, education level, sex, major, academic rank

ANOVA

\begin{tabular}{lllllll}
\hline Model & & $\begin{array}{l}\text { Sum } \\
\text { Squares }\end{array}$ & ofdf & $\begin{array}{l}\text { Mean } \\
\text { Square }\end{array}$ & F & Sig. \\
\hline 1 & Regression & 5.413 & 5 & 1.083 & 3.931 & .002 \\
& Residual & 39.660 & 144 & .275 & & \\
& Total & 45.073 & 149 & & & \\
\hline
\end{tabular}

a. Predictors: (Constant), academic experience, education level, sex, major, academic rank

b. Dependent Variable: work life performance

6.2.7 Effects of Scientific Qualification, Academic Experience, Gender, Major and Academic Rank on the Faculty Member Awareness of Time Management Concept

Using Spearman test for correlation to explore the nature relationship between the five independent variables and the dependent variable (time management awareness) it was found that there is an average reversal relation according to academic experience, as seen in Table (10-1).

Table (10-1). Correlations

\begin{tabular}{|c|c|c|c|c|c|c|c|}
\hline & & $\begin{array}{l}\text { scientific } \\
\text { qualification }\end{array}$ & $\begin{array}{l}\text { academi } \\
\text { rank }\end{array}$ & $\operatorname{sex}$ & major & $\begin{array}{l}\text { academic } \\
\text { experience }\end{array}$ & $\begin{array}{l}\text { Time } \\
\text { management } \\
\text { awareness }\end{array}$ \\
\hline \multirow[t]{3}{*}{$\begin{array}{l}\text { Spearman's } \\
\begin{array}{ll}\text { rho } & \text { management } \\
& \text { awareness }\end{array}\end{array}$} & $\begin{array}{l}\text { Correlation } \\
\text { Coefficient }\end{array}$ & -.023 & -.140 & .149 & -.152 & -.440 & 1.000 \\
\hline & Sig. (2-tailed) & .778 & . 087 & .070 & .064 & .000 & . \\
\hline & $\mathrm{N}$ & 150 & 150 & 150 & 150 & 150 & 150 \\
\hline
\end{tabular}

** Correlation is significant at the .01 level (2-tailed).

* Correlation is significant at the .05 level (2-tailed).

The findings of the test showed that the less experienced teachers are the less aware persons of time management in general. This may be referred to their faith that they know everything about their work and that they manage it correctly, also great connection to their traditional manner regardless of the results.

To investigate the effects of independent variables on the dependent variable multiple regression analysis was carried out to explore the weakness of independent variables ability on explaining the variance or predicting the awareness time management concept among faculty members. It was noted that $\mathrm{R}^{2}$ value is $(0.256)$ and $\mathrm{F}$ value is (9.917) at significance level of (0.00) indicating an effect for all variables on the awareness of time management concept among faculty members as shown in table (10-2). 
Table (10-2). Multi-regression results

Model Summary

\begin{tabular}{lllll}
\hline Model & $\mathrm{R}$ & R Square & $\begin{array}{l}\text { Adjusted } \\
\text { Square }\end{array}$ & RStd. Error of the Estimate \\
\hline 1 & .506 & .256 & .230 & .26 \\
\hline
\end{tabular}

a. Predictors: (Constant), academic experience, education level, sex, major, academic rank

ANOVA

\begin{tabular}{lllllll}
\hline Model & & $\begin{array}{l}\text { Sum } \\
\text { Squares }\end{array}$ & ofdf & Mean SquareF & Sig. \\
\hline 1 & Regression & 3.458 & 5 & .692 & 9.917 & .000 \\
& Residual & 10.042 & 144 & $6.974 \mathrm{E}-02$ & & \\
& Total & 13.500 & 149 & & & \\
\hline
\end{tabular}

a. Predictors: (Constant), academic experience, education level, sex, major, academic rank

b. Dependent Variable: Time management awareness

\section{Conclusions}

1) Faculty members depend on the prescheduled tasks and occasions set by the university administration for planning their teaching classes and courses.

2) Absence of significant relation between the independent variables which should influence the teacher's performance and the planning awareness means illogic academic planning awareness, and other not related variables affect their awareness and academic performance in a "very good" average.

3) Unfortunately, higher scientific qualification doesn't mean better organizing awareness, which could lead to a lower ability of free organizing in non curricula activities, or in life activities.

4) Unfortunately, higher academic experience doesn't mean better execution or evaluation awareness, which could lead to a lower ability of free execution or evaluation in non curricula activities, or in life activities.

5) Unfortunately, higher academic experience doesn't mean better awareness of time management concept, which could lead to a lower ability of using time effectively in academic or life activities.

6) Having no or low positive relations between the independent variables (except gender) and dependent ones means the need for developing programs for the university teachers, in order to improve their awareness and qualifications in time aspect.

\section{Recommendations}

1) Conducting workshops and training courses to enhance faculty members`awareness about time management.

2) Observing faculty members performance according to scheduled plans.

3) Evaluating faculty members' performance accurately within effective plans.

\section{References}

Birth, Kevin, Keuthe. (1993). Any Time is Trinidad Time, time and social organization in eastern trended, University of California, Sandieco.

Forsyth, Patrick. (1996). First Things First, $\left(1^{\text {st }}\right.$ ed). London Bell and Bain Ltd, Clasyow.

Haynes, M. (2002). Time management (Translator: Bilal Abdullah). Al-Riyadh: Dar Al-marefeh.

Machenizie, Alec. (1990). Team Work Through Time Management. Doubnell, comporation, 4, 49.

Mackenzie, A. (1989). Time for Success a Goal Getters Strategy. Me Grow-Hill New York: Mcgraw.

Marsh. W. (1991). Time Management. Cpa Journal, 60, Jan.

Plater, William. M. (1995). Future work- Faculty Time in the 21 century, Change Journal, 27(13).

Robbins, Stephen P., \& Coulter, Mary. (1999). Management, $6^{\text {th }}$ ed, NJ prentice. Hall, Inc. 


\section{Appendix 1.}

Awareness of planning

\begin{tabular}{lll}
\hline & Frequency & Percent \\
\hline v.good & 80 & 53.3 \\
good & 70 & 46.7 \\
Total & 150 & 100.0 \\
\hline
\end{tabular}

Awareness of Organization

\begin{tabular}{lll}
\hline & Frequency & Percent \\
\hline v.good & 37 & 24.7 \\
good & 112 & 74.7 \\
bad & 1 & .7 \\
Total & 150 & 100.0 \\
\hline
\end{tabular}

Awareness of Execution

\begin{tabular}{lll}
\hline & Frequency & Percent \\
\hline good & 125 & 83.3 \\
bad & 25 & 16.7 \\
Total & 150 & 100.0 \\
\hline
\end{tabular}

Awareness of Evaluation

\begin{tabular}{lll}
\hline & Frequency & Percent \\
\hline v.good & 44 & 29.3 \\
good & 77 & 51.3 \\
bad & 29 & 19.3 \\
Total & 150 & 100.0 \\
\hline
\end{tabular}

Role of time management in Personal life

\begin{tabular}{lll}
\hline & Frequency & Percent \\
\hline v.good & 30 & 20.0 \\
good & 81 & 54.0 \\
bad & 39 & 26.0 \\
Total & 150 & 100.0 \\
\hline
\end{tabular}

Role of time management in Job life

\begin{tabular}{lll}
\hline & Frequency & Percent \\
\hline excellent & 4 & 2.7 \\
v.good & 75 & 50.0 \\
good & 71 & 47.3 \\
Total & 150 & 100.0 \\
\hline
\end{tabular}

Awareness of Time management in general:

\begin{tabular}{lll}
\hline & Frequency & Percent \\
\hline v.good & 15 & 10.0 \\
good & 135 & 90.0 \\
Total & 150 & 100.0 \\
\hline
\end{tabular}

